\title{
Development of Hot-Air Supplemented Solar Dryer for White Yam (Dioscorea Rotundata) Slices
}

\author{
T. O. Aduewa ${ }^{1}$, A. S. Ogunlowo ${ }^{2}$ and S. T. Ojo ${ }^{3}$ \\ 1(Department of Agricultural Engineering, Federal University of Technology, P.M.B. 704 Akure, Nigeria) \\ 2(Department of Agricultural Engineering, Federal University of Technology, P.M.B. 704 Akure, Nigeria) \\ 3(Department of Agricultural Engineering, Federal University of Technology, P.M.B. 704 Akure, Nigeria)
}

\begin{abstract}
In this study, a hot-air supplemented solar dryer was designed and fabricated for drying white yam slices Dioscorea rotundata. The capacity of the designed hot-air supplemented solar dryer was $14 \mathrm{~kg}$. The equipment was tested in Federal University of Technology Akure (FUTA) using white yam Dioscorea rotundata to establish the effect of incorporating the hot-air section into the solar dryer. Drying experiments were conducted using a temperature of $60{ }^{\circ} \mathrm{C}$ for the hot-air supplemented solar drying process at a drying air velocity of $0.8 \mathrm{~m} / \mathrm{s}$. After the experiment, it was deduced that the total drying time used to reduce the moisture in the white yam slices to safe storage moisture content (SSMC) differs for the two different drying conditions giving a total drying time of 18 hours for solar dryer and 13 hours for hot-air supplemented solar dryer. The average dryer thermal efficiency for the solar dryer was $31.45 \%$, and the average dryer thermal efficiency is $42.10 \%$ at solar/mechanical drying at $60{ }^{\circ} \mathrm{C}$, and also the solar collector highest efficiency was calculated to be $83.28 \%$ at solar radiation intensity of $1199.46 \mathrm{~W} / \mathrm{m}^{2}$ and lowest efficiency of the solar collector was $23.89 \%$ at solar radiation intensity of $300.40 \mathrm{~W} / \mathrm{m}^{2}$.
\end{abstract}

Keywords: Drying, solar collector, solar dryer, solar radiation, white yam.

\section{Introduction}

In recent years, attempts have been made to develop solar dryers that can be used in agricultural activities in developing countries. Sun drying is still the most common method used to preserve agricultural products in most tropical and subtropical countries. Some of the problems associated with open-air sun drying can be solved through the use of a solar dryer which comprise of collector, a drying chamber and sometimes a chimney [1]. The use of solar technology has often been suggested for the dried fruit and tuber industry both to reduce energy costs and economically speed up drying which would be beneficial to final quality [2]. [3] Dried grapes, okra, tomato and onion using solar energy. They concluded that drying time reduced significantly resulting in a higher product quality in terms of colour and reconstitution properties. One significant limitation of solar dryer is that it can only be used during the daytime when there is adequate solar radiation. This will limit production, and moreover it can result in an inferior product. For commercial producers, the ability to process continuously with reliability is important to satisfy their markets. Some dryers are coupled to solar collector to increase inlet temperature and consequently reduce relative humidity [4]; [5]. In solving this problems of fluctuating and unstable temperature ranges in the drying chamber, there is need to develop a solar dryer that can be conditioned and regulated so as to produce a more marketable products.

The objectives of the research work are to design and fabricate a hot-air supplemented solar dryer for white yam slices; and evaluate the performance of the hot-air supplemented solar dryer over indirect solar dryer.

\section{Theory, Materials And Methods}

2.1 Design Calculation for the Hot-air Supplemented Solar Dryer

\subsubsection{Angle of Tilt ( $\beta$ ) of the Solar Collector/ Air Heater}

According to [6], the angle of tilt $(\beta)$ of a solar collector should be

$\beta=10^{\circ}+$ lat $\varphi$

Where: $\varphi$ is the angle of the solar collector location.

\subsubsection{Insulation on the Collector Surface Area}

Based on the data collected from the meteorological station in Akure in Ondo State, average daily radiation $\mathrm{H}$ on horizontal surface for Akure is $580.85 \mathrm{~W} / \mathrm{m}^{2}$ [7] which almost same value used in some research papers from [8];[9],

According to [10],

Insolation $=I_{c}=H_{T}=H \times R$

$\mathrm{H}$ is the average daily radiation on horizontal surface 
$\mathrm{R}$ is the ratio of solar energy on tilted surface to that on the horizontal surface $R=\frac{T_{x}}{H} \quad[11]$

\subsubsection{Determination of Collector Area and Dimension}

The mass flow rate of air $\mathrm{M}_{\mathrm{a}}$ was determined by taking the average air speed $\mathrm{V}_{\mathrm{a}}=0.15 \mathrm{~m} / \mathrm{s}$ [7]

The air gap height was taken as $10 \mathrm{~cm}=0.10 \mathrm{~m}$ and the width of the solar collector was assumed to be $70 \mathrm{~cm}=$ $0.70 \mathrm{~m}$

Thus, the volumetric flow rate of air $V_{a}^{\prime}=V_{a} \times$ air gap height $\times$ width of collector

$V_{a}^{\prime}=0.0105 \mathrm{~m}^{\mathrm{a}} / \mathrm{s}$

$M_{\alpha}=0.01344 \mathrm{~kg} / \mathrm{s}$

Area of collector $\mathrm{A}_{\mathrm{c}}$

$A_{c}=\frac{M_{a} \times C_{D} \times\left(T_{0}-T_{a}\right)}{0.5 \times I_{c}}[11]$

Where,

$\mathrm{C}_{\mathrm{p}}=$ specific heat capacity of air, $\mathrm{T}_{\mathrm{o}}=$ Optimum temperature for the dryer

$\mathrm{T}_{\mathrm{a}}=$ air inlet temperature at ambient temperature, $\mathrm{I}_{\mathrm{c} \max }=\max$ insulation on the collector surface

$A_{c}=0.89 \mathrm{~m}^{2}$

The length of the solar collector (L) was taken as $L=\frac{A_{\varepsilon}}{B}$

$L=1.27 \mathrm{~m}$

\subsubsection{Determination of the Base Insulation Thickness for the Collector}

The rate of heat loss from air is equal to the rate of conduction through the insulation.

The following equation holds for the purpose of this design according to [12],

$F M_{a} C_{p}\left(T_{0}-T_{i}\right)=\frac{A_{c} K_{a}\left(T_{0}-T_{a}\right)}{t_{b}}$

Where,

$\mathrm{k}=$ thermal conductivity for fibre glass, $\mathrm{F}=$ insulation factor, $\mathrm{T}_{\mathrm{b}}=$ base thickness

$t_{b}=2.6 \mathrm{~cm}$

\subsubsection{Determination of Heat Losses from the Solar Collector}

The total heat transmitted and absorbed is given by [11], as

$I_{c} A_{c} \tau_{\alpha}=Q_{u}+Q_{1}+Q_{\varepsilon}$

Where $\mathrm{Q}_{\mathrm{s}}$ is the energy stored which is considered negligible therefore,

$I_{c} A_{c} \tau_{\alpha}=Q_{u}+Q_{1}$

$\mathrm{Q}_{\mathrm{I}}$ is the heat energy loss

$Q_{1}=I_{c} A_{c} \tau_{\alpha}-Q_{u}$

Since,

$Q_{u}=M_{a} C_{p}\left(T_{0}-T_{i}\right)=M_{a} C_{p}(\Delta T)$

$U_{1}=\frac{I_{c} A_{c} \tau_{\alpha}-M_{a} C_{p}(\Delta T)}{A_{c} \Delta T}$

$\mathrm{U}_{\mathrm{l}}=8.126 \mathrm{~W} / \mathrm{m}^{2 \circ} \mathrm{C}$

Therefore,

$Q_{1}=216.9 \mathrm{~W}$

The quantity of heat loss from the solar collector is $216.9 \mathrm{~W}$

This includes the heat loss through the insulation from the sides and cover glass.

\subsubsection{Selection of the Electric Heater}

power rating $=\frac{\text { Quantity of heat }}{\text { time }}$

power $=0.162 \mathrm{Kw}$

Power rating is $0.162 \mathrm{Kw}$.

2.1.7 Design Consideration for the Fan

fan power $=\frac{\text { air flow rate xstatic pressure (in.water) }}{6320 \times \text { fan efficiency }}$ [13]

Using the maximum efficiency for vane axial fan, this equals $85 \%$ according to AMSE standard.

Fan power $=0.1819 \mathrm{Hp}$ 
An axial van flow fan of $0.2 \mathrm{Hp}$ and 1.6 Inch of water static pressure should be used to ensure proper distribution of air in the drying chamber.

\subsection{Principle of Operation}

The dryer consist of a solar collector chamber, heater housing and a drying chamber. The basic structure of the drying chamber is a timber frame and walls of plywood outside and galvanized metal sheet inside, with drying trays were made from stainless wire mesh and galvanized angle iron frame suspending like drawers. The dryer has a door, which opens at the height of the trays. The dryer uses a dual operation mechanism. In the first mechanism, the solar dryer uses a natural convection to move the hot air generated from the collector chamber into the drying chamber. The second mechanism make use of the supplemented hot air generated from electric filament distributed with the aid of an axial fan placed under the electric heating filament in the heater housing. The heater and the blower have regulators that make it easy to regulate the amount of heat in the chamber to the desired degree. Air vents at the top and bottom allow air to pass through. These can be adjusted to allow for more or less air circulation in hotter or cooler climates, and to regulate the temperature inside the drying chamber. When the vents are open, the hot air rises after being preheated by the effect of solar radiation and escapes through the upper vents. While the cooler air at ambient temperature enters through the lower vents. The convection current set up then leaves the upper vents. All the vents were closed off with mosquito net to prevent insect penetration.

The sun collector is set to face the southern direction, with a tilt corresponding to the latitude of location of use (Akure), so as to face the sun at midday. Inside the collector, a piece of black painted metal absorbs energy from the sun and warms up. A sheet of galvanized metal stores a lot of heat and ensures that the air keeps moving even when the sun goes behind a cloud. The absorber was secured in the middle of the collector to allow free air flows above, through and below. The pictorial illustration of the dryer can be seen in Figs. 1, 2 and 3 below.

Buoyant forces in the dryer induce the airflow due to differences in air density, which synchronizes with pressure drops across the crop stacks. The working temperature of this project is the temperature at the upper vent minus the temperature at the lower vent of the dryer, which depends on the speed of the air current set up, the heat capacity of the air, the absorptivity of the absorber, the amount of heat generated by the heater, the speed of the blower and the rate of heat loss from the sides of the dryer.

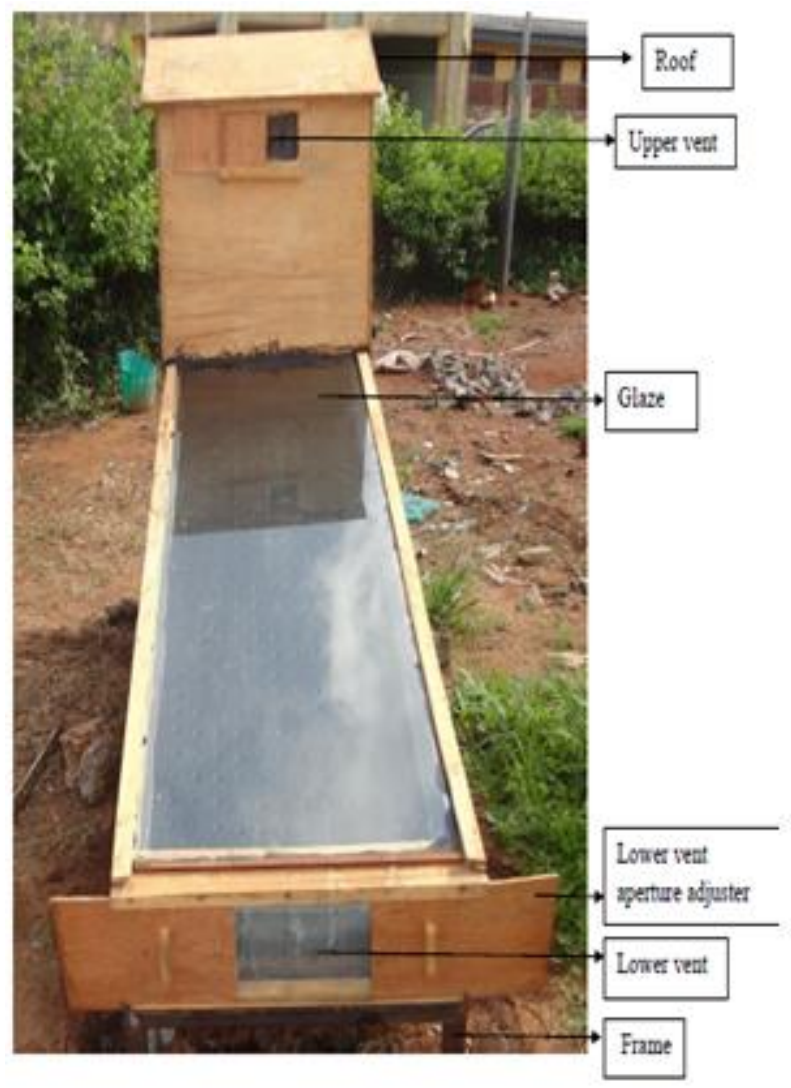

Figure 1: Front view of the hot-air supplemented solar dryer

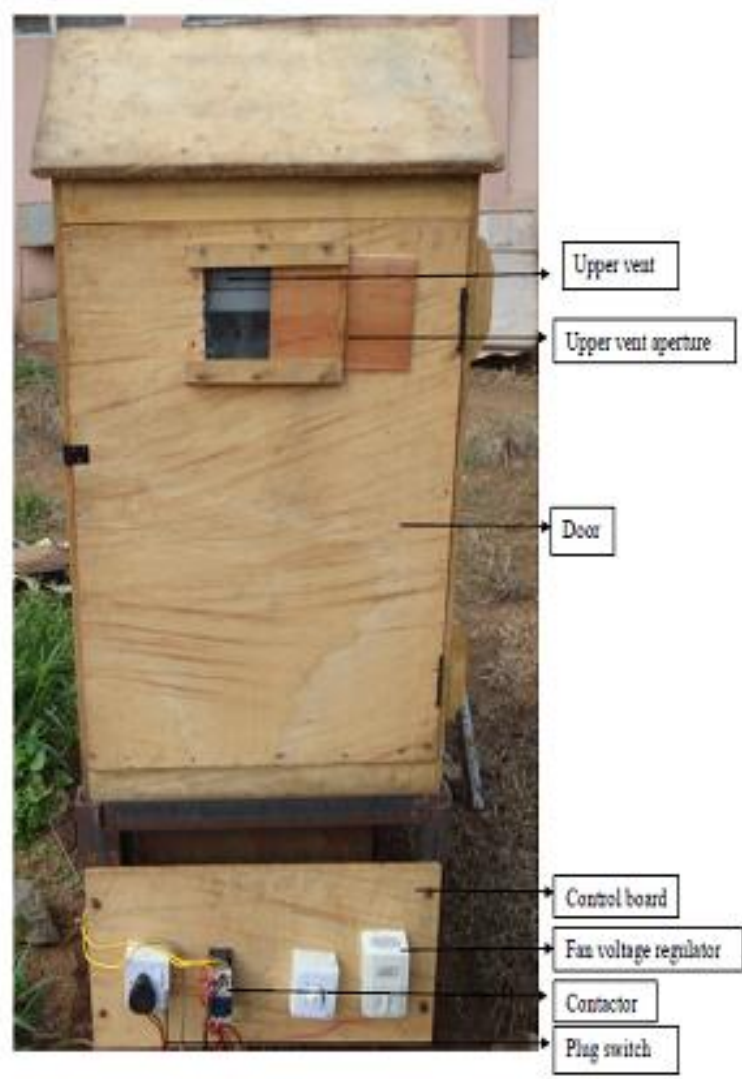

Figure 2: Back view of the dryer 




Figure 3: Picture of the heating element and the axial fan

\subsection{Description of the Study Area}

Akure is located on lat $7^{\circ} 15^{\prime} \mathrm{N}$ and Longitude $5^{\circ} 17^{\prime} \mathrm{E}$ at an altitude of $370 \mathrm{~m}$. From the climatic data analyzed, the temperature of Akure is relatively high throughout the year, with March having the highest mean monthly temperature of $29.6{ }^{\circ} \mathrm{C}$ and August records the lowest mean monthly temperature of $25.4{ }^{\circ} \mathrm{C}$. Akure experiences a high relative humidity, the month of August records the highest mean monthly relative humidity of $85.95 \%$, and the month of January records the lowest mean monthly relative humidity of $64.37 \%$, this connotes that Akure's climate is a warm humid climate that is characterized with low diurnal temperature range high humidity and generally high temperatures. Akure experience a vertical solar insolative mid day sun with a much concentrated solar insolative, from the climatic data sheet, the month of September records the highest mean duration of sunshine for 8 hours [7].

\subsection{Material Preparation}

Prior to the commencement of the experiment, the purchased yam was washed to get rid of dirt and debris using tap water. It was further peeled using a clean stainless kitchen knife and then was cut into the required thickness of either $2 \mathrm{~mm}$ or $4 \mathrm{~mm}$ using mechanical slicing machine. The yam slice was then weighed using a weighing balance and then blanched. The blanching was carried out in order to help in control browning process and also cellular exchanges and nutrients losses [14] and [15]. And this was done by soaking the sliced yam in a boiled water of $70{ }^{\circ} \mathrm{C}$ for a period of 30 minutes according to [14]. After this, the blanched yam slices were drained using a plastic sieve and then placed in the drying tray of the dryer.

\subsubsection{Drying Procedures}

In each drying run of experiments, $250 \mathrm{~g}$ prepared white yam was used. At the start of the experiment, the dryer was run idle for an hour to reach thermal stability. After which the prepared samples of white yam which was uniformly spread within the tray mesh as a single layer is placed in the drying chamber of the dryer. The drying experiments were carried out at air velocity of $0.8 \mathrm{~m} / \mathrm{s}$, air temperature used was, $60{ }^{\circ} \mathrm{C}$. These conditions are normally used for air drying of biological materials [16]; [17]. The thicknesses used were $2 \mathrm{~mm}$ and $4 \mathrm{~mm}$. the sample mass was recorded at an hour interval using a digital weighing balance until no further changes in mass was recorded for next 2 hours [18]. These procedures were followed for each run corresponding to the 2 by 1 factorial designs where the thickness is $2 \mathrm{~mm}$ and $4 \mathrm{~mm}$, the air velocity is $0.8 \mathrm{~m} / \mathrm{s}$ and temperature were and $60{ }^{\circ} \mathrm{C}$.

The experiment was conducted on two different drying systems. The first drying experiment was conducted using the solar drying system alone. During this drying experiment, the sliced yam was placed in the drying system while the hot-air supplemented chamber was closed to allow direct inflow of hot air generated via the solar collector plate into the drying chamber.

The second drying experiment was conducted with the combination of solar drying system and the hotair incorporated system. In the experimental run, the temperature in the drying chamber was regulated to ensure stability of the drying chamber temperature.

For the two drying experiment, readings were taken and recorded hourly. 


\subsection{Evaluation Parameters}

\subsubsection{Collector Efficiency $(\eta)$}

The efficiency of a flat plate solar collector can be computed according to [19],

$\eta=\frac{\rho V c_{p} \Delta T}{A I_{c}}$

Where:

$\rho$ is the density of air $\left(\mathrm{kg} / \mathrm{m}^{3}\right), I_{c}$ is the insulation on the collector

$\Delta \mathrm{T}$ is the temperature elevation, $\mathrm{V}$ is the volumetric flow rate $\left(\mathrm{m}^{3} / \mathrm{s}\right)$,

$\mathrm{C}_{\mathrm{p}}$ is the specific heat capacity of air at constant pressure $(\mathrm{J} / \mathrm{KgK})$, and

$\mathrm{A}$ is the effective area of the collector facing the collector facing the sun $\left(\mathrm{m}^{2}\right)$

\subsubsection{Dryer Efficiency $\left(\eta_{\mathrm{d}}\right)$}

The efficiency of solar drying system can be evaluated either based on the thermal performance or drying rates of the products. The process based on drying rates is associated with a number of variables involved and is much complex and tedious for calculation. For this research work, the thermal performance of solar dryer can be defined as the thermal energy utilized for drying over the thermal energy available for drying [19]. But according to [20], [21], and [22], the overall efficiency of solar dryer was simplified based on the equations below:

The thermal energy available for drying through the solar collector $\left(\mathrm{Q}_{\mathrm{c}}\right)$ is given as:

$Q_{c}=A_{c} I(\alpha \tau)[19]$

Where,

$\mathrm{I}=$ intensity of solar radiation incident on the collector surface $\left(\mathrm{W} / \mathrm{m}^{2}\right), \mathrm{A}_{\mathrm{c}}=$ area of the collector $\left(\mathrm{m}^{2}\right)$

$\alpha=$ absorptivity of the collector plate, and $\tau=$ transmissivity of collector glazing.

$\mathrm{Q}_{\mathrm{c}}=288.71 \mathrm{~W} / \mathrm{m}^{2}$

The thermal energy utilized for drying $\left(\mathrm{Q}_{\mathrm{u}}\right)$ includes the following:

(i) Sensible heat used to raise the temperature of food $\left(\mathrm{Q}_{\mathrm{sf}}\right)$;

$$
Q_{s f}=m_{f} C_{p f}\left(T_{2}-T_{1}\right) \quad \text { [22] }
$$

Where,

$\mathrm{m}_{\mathrm{f}}=$ mass of dried food content $(\mathrm{kg}), \mathrm{T}_{1}$ and $\mathrm{T}_{2}=$ initial and final temperatures $(\mathrm{K})$.

$\mathrm{C}_{\mathrm{pf}}=$ specific heat capacity of dried food at constant pressure (J/kg.K)

(ii) Sensible heat used to raise temperature of the water in the food $\left(\mathrm{Q}_{\mathrm{sw}}\right)$;

$Q_{S W}=m_{w W} C_{p w}\left(T_{2}-T_{1}\right)$ [22]

Where,

$\mathrm{m}_{\mathrm{w}}=$ mass of water content $(\mathrm{kg})$; and, $\mathrm{C}_{\mathrm{pw}}=$ specific heat capacity of water at constant pressure $(\mathrm{J} / \mathrm{kg} . \mathrm{K})$.

(iii) Latent heat used to vaporize the water in the food $\left(\mathrm{Q}_{\mathrm{lw}}\right)$;

$Q_{\mathrm{Ww}}=m_{v} L_{v}[22]$

Where,

$\mathrm{m}_{\mathrm{v}}=$ mass of water vapour $(\mathrm{kg})$; and $\mathrm{L}_{\mathrm{v}}=$ latent heat of vaporization $(\mathrm{J} / \mathrm{kg})$.

Therefore,

$Q_{u}=Q_{s f}+Q_{s w}+Q_{\mathrm{iw}}[22]$

Or

$Q_{u}=\left(m_{f} C_{p f}+m_{v w} C_{p w}\right)\left(T_{2}-T_{1}\right)+m_{v} L_{v}[19]$

The thermal efficiency of solar dryer $\left(\eta_{\mathrm{d}}\right)$ is the ratio of the thermal energy utilized for drying $\left(\mathrm{Q}_{\mathrm{u}}\right)$ over the thermal energy available for drying through the solar collector $\left(\mathrm{Q}_{c}\right)$.

$\eta_{d}=\frac{\left(m_{f} c_{p f}+m_{w v} c_{p w}\right)\left(T_{2}-T_{1}\right) m_{\mathrm{v}} L_{v}}{A_{\mathrm{c}} I(\alpha \tau)}$

\subsection{Moisture Content of White Yam}

\section{Results And Discussion}

The initial moisture content of white yam after drying in three replicates and taking the average was found to be $73.1 \%$ w.b. This value agreed well with the reports from the literature about thermo-physical properties of yam as investigated by [23]; [24] and [21].

\subsection{Variation of Drying Parameter with Weather Condition at No Load}

The first experimental test carried out was at no load when the solar dryer was tested without loading into it any yam slices. Solar dryer system alone was used to carry out a no load test for two days. During the second day testing, fluctuating temperature reading were taken inside the drying chamber which was due to the inability to control the climatic condition. As shown in Fig. 4, the dryer temperature was always at the peak 
temperature between the hours of $1300 \mathrm{hrs}$ to $1500 \mathrm{hrs}$ giving a temperature between $50{ }^{\circ} \mathrm{C}$ to $69{ }^{\circ} \mathrm{C}$. The between the hours of $1500 \mathrm{hrs}$ and $1700 \mathrm{hrs}$, there is a fall in level of temperature in the dryer giving a temperature of as low as $40{ }^{\circ} \mathrm{C}$.

The hot-air supplemented solar dryer was also tested at no load with a preset temperature of $50{ }^{\circ} \mathrm{C}$. The dryer temperature was stable and maintained at $50{ }^{\circ} \mathrm{C}$ but with the outlet temperature higher that the dryer temperature during the hours of $1200 \mathrm{hrs}$ and $1300 \mathrm{hrs}$. This increase occurred as a result of no work done in the dryer and also accumulated heat during the period when the ambient temperature was at its peak. Fig. 4 clearly shows the variation of the drying parameter with weather conditions.

\subsection{Variation of Drying Parameter with Weather Condition at Full Load}

White yam slices were dried using solar dryer and combination of solar and mechanical dryer at $60{ }^{\circ} \mathrm{C}$ to investigate the stability of temperature in the drying chamber. The temperature curves in the drying chamber throughout the experimental period were shown in Fig. 4 to Fig. 6 for the two drying systems as related to the solar radiation intensity, ambient temperature and solar collector air temperature.

There was fluctuation in the temperature level in the drying chamber while using solar dryer alone and this will in turn affect the drying rate and also the time of drying which will eventually affect the colouration of the yam after drying due to long drying time. The maximum temperature attained in the drying chamber during this drying process was $69.5{ }^{\circ} \mathrm{C}$ at $1169 \mathrm{~W} / \mathrm{m}^{2}$ and this temperature was not stable throughout the drying process.

The drying temperature was stable and controlled while drying with the incorporation on mechanical drying system making it more efficient dependable. The drying temperatures in the drying cabinets were shown in Fig. 6 similar trends were also reported by [21], during the experimental determination of the moisture content pattern in yam and [25], during the experimental testing of combined solar and mechanical dryer. The results were similar to earlier observation on drying of two species of cocoyam by [26].

During the drying process, once the ambient temperature is at its peak and if it is higher than the preset temperature, thermostat breaks the power supply to the heating element making only the fan to be at work blowing the excess heat out of the drying chamber making the outlet temperature to be higher the drying chamber temperature and this was experienced throughout the experimental period and this can be seen in Fig. 6.

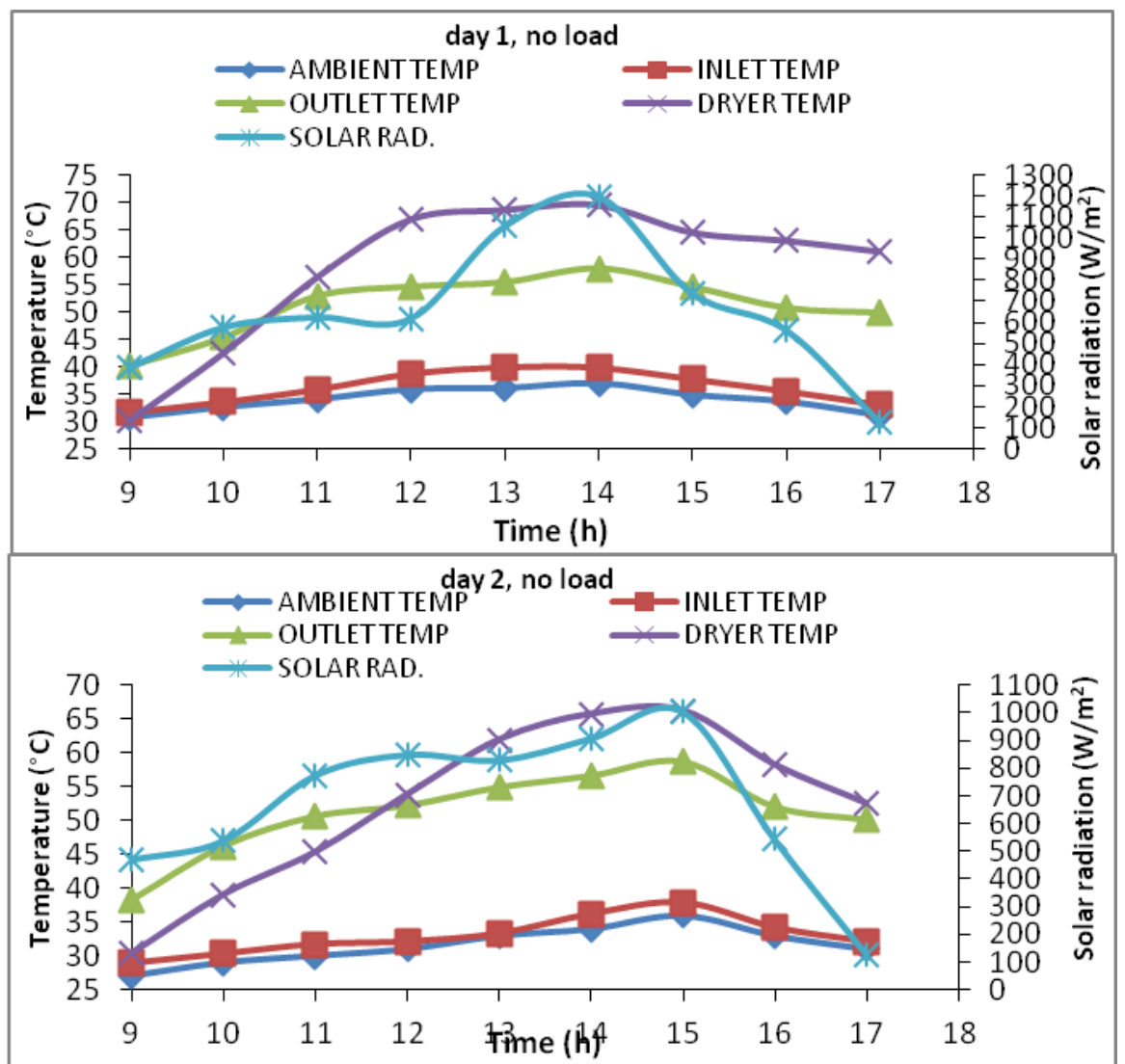




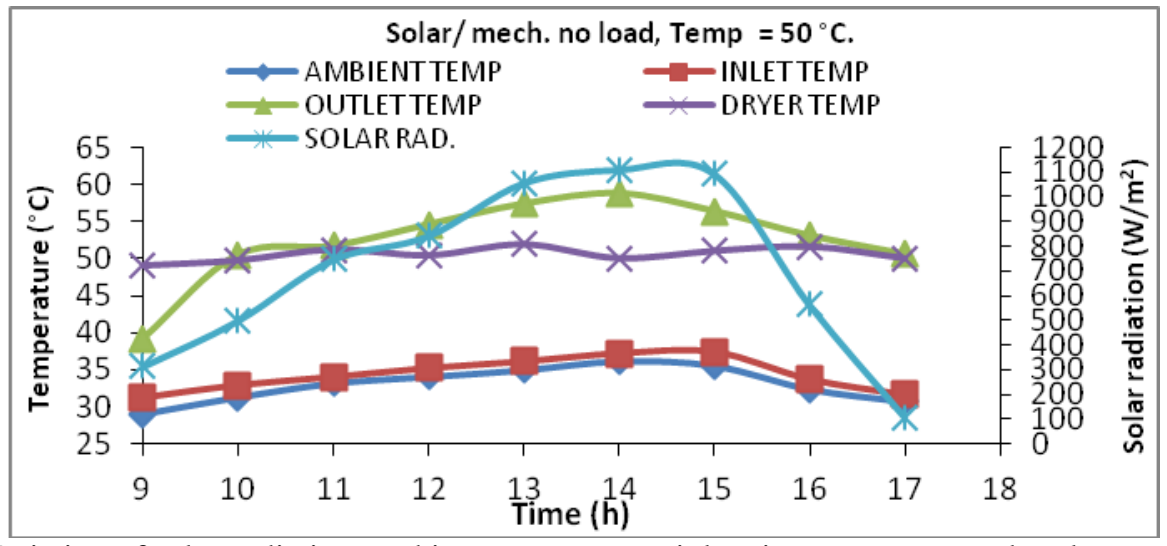

Figure 4: Variation of solar radiation, ambient temperature, inlet air temperature and outlet temperature and drying chamber temperature with time at no load test.



Figure 5: Variation of solar radiation, ambient temperature, inlet air temperature and outlet temperature and drying chamber temperature with time during solar drying test at full load. 


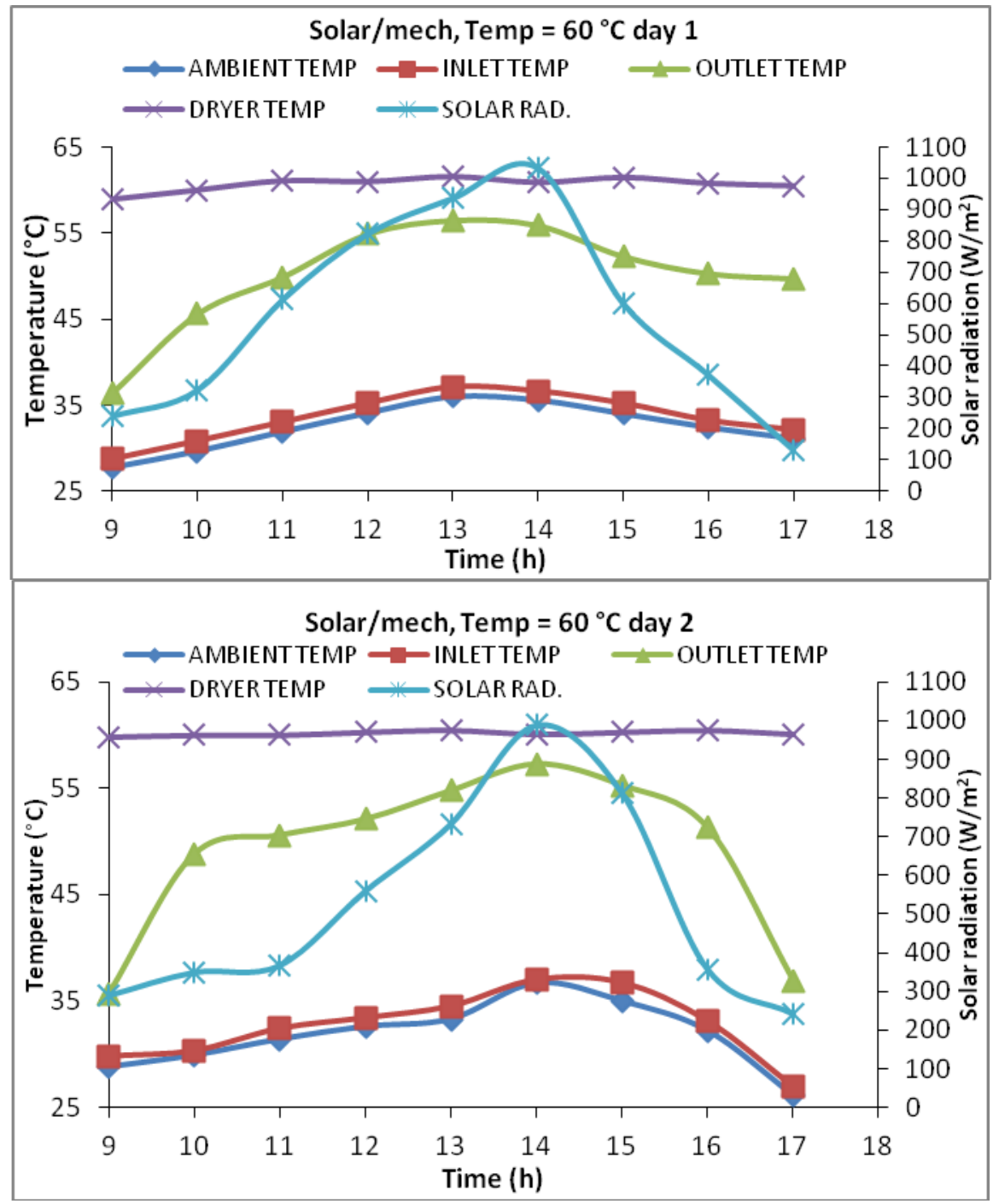

Figure 6: Variation of solar radiation, ambient temperature, inlet air temperature and outlet temperature and drying chamber temperature with time during solar/mechanical drying test at $60{ }^{\circ} \mathrm{C}$ at full load.

\subsection{Solar Collector Performance}

The performance test for the solar air collector was conducted. Figs. 4, 5 and 6 above show temperatures of the atmosphere, air temperatures (inlet and outlet) of the solar collector temperature and intensity of solar radiation per unit area. The highest air temperature $\left(59.9^{\circ} \mathrm{C}\right)$ of the outlet solar collector air temperature was obtained with solar radiation intensity of $1199.464 \mathrm{~W} / \mathrm{m}^{2}$ as shown in Fig. 4 and the lowest was $33.3{ }^{\circ} \mathrm{C}$ at solar radiation intensity of $300.408 \mathrm{~W} / \mathrm{m}^{2}$.

The efficiency of the solar collector depends on the air flow rate and the difference in temperature and radiation intensity was obtained at the highest efficiency of the solar collector giving an efficiency of $83.28 \%$ at solar radiation intensity of $1199.46 \mathrm{~W} / \mathrm{m}^{2}$ and the lowest efficiency of the solar collector was $23.89 \%$ at solar radiation intensity of $300.408 \mathrm{~W} / \mathrm{m}^{2}$ which gives a better solar collector efficiency result compared to that that of [21], [19] and [22].

\subsection{Efficiency of the Solar Dryer}

Based on the equations in the literature, the efficiency of the solar dryer was evaluated and the results were given based on different drying conditions. Variations in the drying efficiency of the solar drying system for different drying conditions and temperatures were shown in the Fig. 7 below. The average dryer thermal efficiency for the solar dryer was $31.45 \%$, and the average dryer thermal efficiency is $42.10 \%$ at solar/mechanical drying at $60^{\circ} \mathrm{C}$.

Fig. 7 shows the graphical representation of the drying system efficiency with respect to the average drying temperature range. 


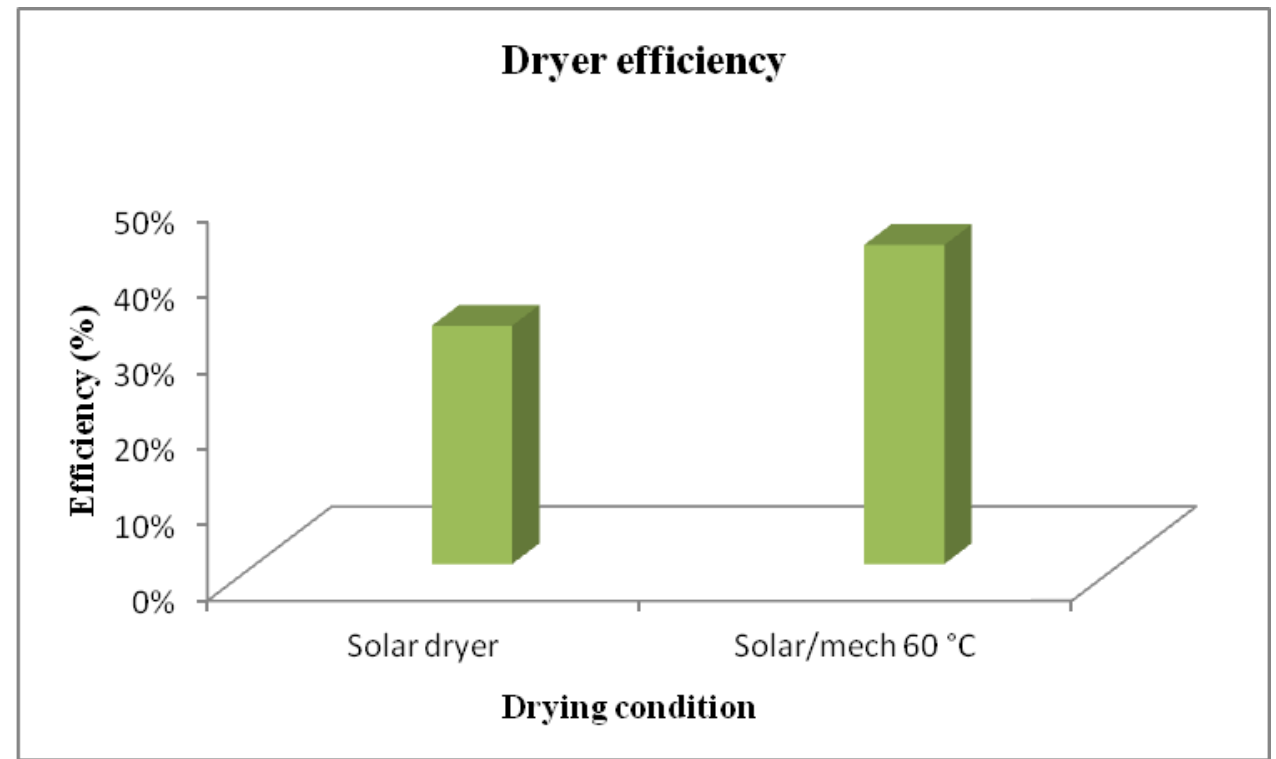

Figure 7: Variation of machine drying efficiency for different drying system

\subsection{Conclusion}

\section{Conclusions And Recommendations}

A hot-air supplemented solar dryer was designed and fabricated. The three main components of the solar dryer are the drying chamber that houses 3 trays, the solar collector and the heater housing that has a heating filament and an axial flow fan. The dryer intends to maximize the use of energy available from the sun and also coupled with the hot air derived from the electric filament and axial fan to hasten and also ensure a faster rate of drying. The results of the experimental tests carried out on the dryer indicated that the dryer is to a large extent effective in dehydrating yam slices reasonably and rapidly to a safe moisture level not been conditioned by weather factors. The validation test was first conducted at no-load operating condition using solar drying system alone having maximum air temperatures of $39.4^{\circ} \mathrm{C}, 59.9^{\circ} \mathrm{C}$ and $69.5^{\circ} \mathrm{C}$ were obtained in the inlet of the absorber, outlet of the absorber and the drying chamber respectively, while the maximum ambient air temperature obtained was $36.9{ }^{\circ} \mathrm{C}$. Also, validation test was conducted at no-load operating condition using combination of solar and mechanical drying system at $50{ }^{\circ} \mathrm{C}$ to experiment the stability if the drying chamber air temperature.

\subsection{Recommendations for Future Studies}

From the conclusions made during the study, the following recommendations are made:

a) Performance evaluation of the drying systems should be carried out in order to analyse the efficiency of the system using other agricultural materials.

b) Modelling of the drying data and heat and mass transfer simulation using simulation software is also suggested.

c) Solar panel should be incorporated so as to make the mechanical drying system solar powered and see the effect on the drying system and production cost.

\section{References}

[1]. Madhlopa, A., Jones, S. A. and Kalenga-Saka, J. D. (2002). A solar air heater with composite absorber systems for food dehydration. Renewable Energy, 27: 27-37.

[2]. Lambert, J. M., Angus, D. E. and Reid, P. J. (1980). Solar energy applications in agriculture. The dried vine industry. (University of Melbourne, Australia). Pp 68-74.

[3]. El-Shiatry, M. A., Muller, J. and Muhlbauer, W. (1991). Drying fruits and vegetables with solar energy in Egypt. AMA, 22(4): 61 64.

[4]. Selkuc, M. K., Resay, O. and Akyurt, M. (1974). Development, theoretical analysis and performance evaluation of shelf type solar driers, Solar Energy, 16: 81-88.

[5]. Eissen, W., Muhlbauer, W. and Kutzbach, H. D. (1985). Solar drying of grapes. Drying Technology, 3(1): 63-74.

[6]. Sukhatme, S. P (1996). Solar-energy principles of thermal collection and storage, (Tata McGraw Hill Publishing Company Limited) Pp 45-60.

[7]. NiMet (2013). Nigeria Meteorological Agency, Department of Civil Aviation, Federal Secretariat, Igbatoro Akure, Ondo State.

[8]. Oladosu, O. R., Adediji, A. T., Ojo, J. S. and Adegbite, A. (2012). Daily averages of solar radiation measured at Iju, Nigeria in 2008. International Journal of Physical Sciences Vol. 7(27), pp. 5026-5035.

[9]. Falodun, S. E. and Ogolo, E. O. (2009). diurnal and seasonal variations of global solar radiation at Akure, South- Western Nigeria. Journal of Engineering and Applied Sciences 2 (1): 125-128. 
[10]. Olaleye, D. O. (2008). The design and construction of a solar incubator, unpublished M. Eng. thesis, Department of Mechanical Engineering, University of Agriculture, Abeokuta.

[11]. Alamu, O. J., Nwachucha C. N. and Adunola O. (2011). Design and construction of a domestic passive solar food dryer, Leonardo Journal of Sciences, Pp.71-82.

[12]. Scalin, D. (1997). The design, construction and use of an indirect, through-pass, solar food dryer, Home Power Magazine, 57, Pp. $62-72$.

[13]. Adzimah, K. S. and Seckley, E. (2009). Improvement on the design of a cabinet grain dryer. American J. of Engineering and Applied Sciences 2 (1): 217-228.

[14]. Akissoe, N., Vernier, P. and Cornet, D., (2006). International society for tropical root crops, Thiruvananthapuram Kerala, India.

[15]. Leng, M. S., Gouado I. and Ndjouenkeu, R. (2011). Blanching and drying behaviour of Dioscorea schimperiana and impact on cellular exchanges and on calcium, ascorbic acid and $\beta$-carotene contents. American Journal of Food Technology, 6: 362-373.

[16]. Goyal, R. K., Kingsly, A. R. P., Manikantan, M. R. and Ilyas, S. M. (2007). Mathematical modelling of thin layer drying kinetics of plum in a tunnel dryer. Journal of Food Engineering 79: 176-180.

[17]. Nguyen, M. and Price, W. E. (2007). Air drying of Banana: Influence of experimental parameters slab thickness, banana maturity and harvesting season. Journal of food Engineering 79: 200-207.

[18]. Sacilik, K. and Unal, G. (2005). Dehydration characteristics of kastamonu Gavlic Slices, Journal of Biosystems Engineering, 209: 49-53.

[19]. Gatea, A. A. (2011). Performance evaluation of a mixed-mode solar dryer for evaporating moisture in beans, Journal of Agricultural Biotechnology and Sustainable Development Vol. 3(4) pp. 65-71.

[20]. Henry, T. S. and Price, W. E. (1999). A diffusion model for prune dehydration. J.Food Eng., 42: 167-172.

[21]. Adelaja, A. O., Asemota, O. S. and Oshiafi, I. K. (2010). Experimental determination of the moisture content pattern in yam during drying, Journal of Applied Sciences Research, Insinet Publication.6(8): 1171-1181,

[22]. Olalusi, A. P. Ogunlowo A. S. and Bolaji B. O. (2012). Development and performance evaluation of a mobile solar dryer for cassava chips, Energy \& Environment Vol. 23, No. 8. Pg 1261-1273

[23]. Oke, M. O., Awonorin, S. O., Oyelade, O. J., Olajide, J. O., Olaniyan, G. O. and Sobukola, P. O. (2009). Some thermo-physical properties of yam cuts of two Geometries. African Journal of Biotechnology Vol. 8 (7), pp. 1300-1304.

[24]. Noche, C. F. Cantre, D. V. and Flores, F. P. (2011). Effect of pretreatment and geometry on the thermophysical properties of raw ubi (Dioscorea alata L.) Philippine Science Letter vol. 4(1). Pp 1-6.

[25]. Bhuiyan, M. H. R., Alam M. M. and Islam M. N. (2011). The construction and testing of a combined solar and mechanical cabinet dryer, J. Environ. Sci. \& Natural Resources, 4(2): 35-40.

[26]. Obot, M. S. (2011). Modelling of hot-air drying characteristics of cocoyam slices in a convective cabinet dryer. M. Eng. thesis unpublished, Federal University of Technology pp 9-60. 